\title{
Effects of fungal pathogens on seeds of native and exotic plants: a test using congeneric pairs
}

Post-print/Accepted manuscript

C. Sean Blaney

Peter M. Kotanen

Blaney, C.S. and Kotanen, P.M. (2001), Effects of fungal pathogens on seeds of native and exotic plants: a test using congeneric pairs. Journal of Applied Ecology, 38: 1104-1113. doi:10.1046/j.1365-

2664.2001.00663.x

This is the peer reviewed version of the following article: Blaney, C.S. and Kotanen, P.M. (2001), Effects of fungal pathogens on seeds of native and exotic plants: a test using congeneric pairs. Journal of Applied Ecology, 38: 1104-1113, which has been published in final form at http://dx.doi.org/10.1046/j.13652664.2001.00663.x This article may be used for non-commercial purposes in accordance with Wiley Terms and Conditions for Self-Archiving.

\section{HOW TO CITE TSPACE ITEMS}

Always cite the published version, so the author(s) will receive recognition through services that track citation counts, e.g. Scopus. If you need to cite the page number of the TSpace version (original manuscript or accepted manuscript) because you cannot access the published version, then cite the TSpace version in addition to the published version using the permanent URI (handle) found on the record page. 


\title{
Effects of fungal pathogens on seeds of native and exotic plants: a test using congeneric pairs
}

\author{
C.S. Blaney* and P.M. Kotanen† \\ Department of Botany, University of Toronto at Mississauga, 3359 Mississauga Road North, \\ Mississauga, Ontario, L5L 1C6 CANADA
}

*Current address: Atlantic Canada Conservation Data Centre, P.O. Box 6416, Sackville, New Brunswick, E4L 1G6, CANADA

†Correspondence author

FAX: 905-828-3792 
e-mail: pkotanen@credit.erin.utoronto.ca

Length: 5093 words excluding references and tables; 7279 overall 


\section{Summary}

$\mathbf{1}$ It has previously been hypothesized that low rates of attack by natural enemies may contribute to the invasiveness of exotic plants.

2 We tested this hypothesis by investigating the influence of pathogens on survival during a critical life-history stage: the seed bank. We used fungicide treatments to estimate the impacts of soil fungi on buried seeds of a taxonomically broad suite of congeneric natives and exotics, in both upland and wetland meadows.

3 Seeds of both natives and exotics were recovered at lower rates in wetlands than in uplands. Fungicide addition reduced this difference by improving recovery in wetlands, indicating that the lower recovery was largely attributable to a higher level of fungal mortality. This suggests that fungal pathogens may contribute to the exclusion of upland species from wetlands.

4 The effects of fungicide on the recovery of buried seeds did not differ between natives and exotics. Seeds of exotics were recovered at a higher rate than seeds of natives in uplands, but this effect was not attributable to fungal pathogens.

5 Fungal seed pathogens may offer poor prospects for the management of most exotic species. The lack of consistent differences in the responses of natives vs. exotics to fungicide suggests few aliens owe their success to low seed pathogen loads, while impacts of seed-pathogenic biocontrol agents on non-target species would be frequent.

Key-words: aliens, fungi, invaders, old fields, seed banks, wetlands 


\section{Introduction}

Non-native plant species deliberately or accidentally introduced into new areas by humans now comprise a substantial fraction of the flora of many ecosystems around the world (Drake et al. 1989; Vitousek et al. 1996; Mack et al. 2000; Manchester \& Bullock 2000). Exotic species can pose serious concerns for the conservation of native species, and may cost millions of dollars in remediation and control efforts (US Congress 1993; Vitousek et al. 1996; Mack et al. 2000). Still, most arriving plant invaders never become established, or have no noticeable impact if they do (Williamson \& Fitter 1996a,b; Manchester \& Bullock 2000). Many researchers have tried to develop guidelines for the identification and control of the minority which will become problematic invaders, but these efforts have produced few rules with strong predictive or management value (Mack 1996; Williamson 1996; Mack et al. 2000; but see Kolar \& Lodge 2001).

Seed banks may provide clues to invasiveness. Many plants suffer the majority of their mortality at the seed stage (Harper 1977; Leck, Parker \& Simpson 1989; Fenner 1992), suggesting seed mortality has the potential to limit invasiveness. The presence of seed banks may also be important in buffering against the stochastic hazards faced by small populations (Venable \& Brown 1988; Stöcklin \& Fischer 1999); invading species generally face these hazards repeatedly, both at the original site of introduction and with range expansion as small colonizing subpopulations are formed (Barrett \& Richardson 1986; Crawley 1989; Barrett \& Husband 1990). It follows that the survival of invading populations may be enhanced in species able to produce persistent seed banks (Baker 1969, 1974), and there is some evidence that this is the case. For example, many invaders produce seed banks, including almost all of the world's worst weeds (Holm et al. 1977), and seed banks are one of the most important factors limiting efforts to biologically control exotic weeds (Holloway 1964; Dahlsten 1986). Crawley, Harvey \& Purvis (1996) found that British aliens were more likely than 
natives to have long term seed banks, though this may not apply equally to all groups (Hodkinson \& Thompson 1997). Finally, Thompson, Hodgson \& Rich (1995) found that many plants recently expanding in their European distribution had persistent seed banks, though this was less likely to be the case for exotics than natives.

Biological factors causing mortality of buried seeds in natural communities are incompletely understood, though they are known to include a wide range of vertebrate and invertebrate seed predators, and many taxa of pathogens (Baskin \& Baskin 1998). Fungi are believed to be among the most important enemies of buried seeds, but few field experiments have addressed their roles specifically (Kremer 1993; Baskin \& Baskin 1998). There are two distinct reasons to expect that exotic plants may exhibit especially great resistance to seed-destroying fungi, with positive consequences for their survival in the seed bank. First, invaders may lose their pathogens when they are transported to a new area (the predator escape hypothesis: Elton 1958; Crawley 1986). Secondly, species intrinsically resistant to seed pathogens may make better invaders because they are less likely to be eliminated by natural enemies during colonization of new areas (the predator filter hypothesis: Blaney \& Kotanen 2001). In both cases, a low pest load is important to invasion, but the escape hypothesis predicts invaders to have reduced pest loads in new habitats, while the filter hypothesis predicts pest loads to be low in both original and new areas. The escape hypothesis also relies on the loss of species-specific enemies, while the filter hypothesis applies to both generalists and specialists.

There is some support for both of these hypotheses. Evidence for the filter hypothesis is relatively sparse, but correlations between seed size, predation rates, and invasiveness (Crawley et al. 1996), together suggest species with low rates of seed predation may make the most successful invaders. Evidence for the escape hypothesis is more extensive. Though many soil-borne disease 
organisms may be non-selective, some are thought to be host-specific (Kirkpatrick \& Bazzaz 1979; Harman 1983; Mills \& Bever 1998), including some seed pathogens of agricultural plants (Neergaard 1977; Agarwal \& Sinclair 1997). A few studies have also demonstrated that invaders develop larger seed banks in new regions than in their native habitats, suggesting that escape from seed predators may be occurring. For example, numerous Australian Acacia spp. develop much larger seed banks in South Africa than in their native regions, primarily as a result of escape from predispersal seed predators and gall rusts (Dean, Holmes \& Weiss 1986). Similarly, seed banks of Chrysanthemoides monilifera are much larger in Australia than in its native South Africa, reflecting both greater seed production and enhanced persistence in the soil (Scott 1996).

In this paper, we investigate whether susceptibility to natural enemies is lower in exotics than in natives, as predicted by both the predator filter and predator escape hypotheses. We have chosen to focus on fungal seed pathogens because of their presumed importance; elsewhere, we also consider vertebrate and invertebrate seed predators (Blaney 1999; Blaney \& Kotanen 2001, unpublished data). Since rates of fungal attack may vary among habitats, we explore this question with linked experiments in two types of communities: wetland and upland meadows. In order to look for recurring patterns, we have used a set of 30 plant species drawn from a wide range of taxonomic groups. Analyses in which species are treated as independent datapoints can be useful in demonstrating community-level ecological patterns, and we have followed this approach in related studies (Blaney 1999; Blaney \& Kotanen 2001, unpublished data), but there is a risk that subtle native-alien differences may be lost in the "noise" created by the inclusion of very different species in the same dataset. As well, if a significant correlation were found between disease resistance and exotic status, it might not represent a causal relationship, but instead might be attributable to some unmeasured characteristic of the taxonomic groups from which the exotic species were drawn 
(Felsenstein 1985; Harvey \& Pagel 1991; Miles \& Dunham 1993). In response, we have employed comparisons within congeneric pairs of native and exotic species; comparing closely-related species reduces the likelihood of phylogenetic biases, and can allow the detection of subtle effects despite using a great diversity of species (Mack 1996). This is one of the few studies to experimentally test a hypothesis of invasiveness (Karieva 1996), and is the first to experimentally study seed bank ecology for a wide range of co-occurring natives and exotics.

\section{Site Description}

The experiment was conducted in 9 upland and 10 open wetland plots, each measuring $2.5 \mathrm{~m}$ by 3.5m, distributed around the 348 ha University of Toronto Joker’s Hill field station, Regional Municipality of York, Ontario $\left(44^{\circ} 02^{\prime} \mathrm{N}, 7^{\circ} 31^{\prime} \mathrm{W}\right)$. Plots of each habitat type were matched for moisture level, openness and vegetation type and were separated by at least $100 \mathrm{~m}$. The upland plots were in open, dry, sandy old field habitats, with some combination of Bromus inermis, Poa pratensis and Poa compressa dominant. The wetland plots were in open, permanently wet meadows, dominated by wetland species including Eupatorium maculatum, Eupatorium perfoliatum, Agrostis stolonifera, Impatiens capensis, Onoclea sensibilis, Glyceria striata, Equisetum arvense, and Equisetum fluviatile. Nomenclature follows Gleason \& Cronquist (1991).

\section{Materials and Methods}

\section{EXPERIMENTAL SPECIES}

Seeds were bulk-collected from wild populations in southern Ontario in 1997, with the exception of Elymus trachycaulus: this species was purchased from the Pterophylla Farm (Walsingham, Ontario), where seeds were grown in 1996 from plants originating from local, wild seed stock. All seeds were stored dry in a freezer until needed. Thirty herbaceous species of open, upland areas were chosen for this experiment, comprising 15 congeneric pairs of one native and one 
alien species (Table 1). Wild populations of each species occur in the Regional Municipality of York (Riley 1989), and most occur naturally within the Joker's Hill property (Table 1). We have defined exotics as species which are regionally or continentally non-native (Morton \& Venn 1990), but not simply as absent from our particular study site or experimental habitats; this reflects the expectation that while seed pathogens may be lost during long-distance invasions, they are unlikely to be unable to disperse between local habitats. Our dataset includes locally common and locally scarce examples of both natives and exotics.

\section{TREATMENTS}

Upland and wetland soil was collected from the study site immediately before the experiment. This soil was dried and sieved but otherwise not treated before use. Seed bags, each made from a knee-high nylon stocking cut in thirds, were filled with 20 seeds of a single species mixed with $20 \mathrm{~mL}$ of field soil and then tied shut. These bags were subjected to one of two treatments: 1) control - seed bag saturated in water before burial and 2) fungicide addition - seed bag saturated in fungicide solution before burial. The fungicide solution was a 1:100 solution of Maestro 75DF in water (Zeneca Corp., Ontario, Canada); this concentration was recommended by the manufacturer for use as a dip for bulbs and tubers. The active ingredient in this fungicide is Captan (75\% by weight). Captan is a non-systemic heterocyclic nitrogen fungicide used against a wide range of fungi in the Oomycota, Ascomycota and Basidiomycotina (Sharvelle 1961; Torgeson 1969; Neergaard 1977) and is noted as being particularly effective against seed-rotting fungi (Neergaard 1977). It has been shown to have minimal effects on endomycorrhizal fungi, which are important in grassland systems (Dix \& Webster 1995), but can have both positive and negative effects on ectomycorrhizal development depending on the plant species involved (Vyas 1988). 
Within each experimental plot, a 10 x 6 grid was created with points separated by $0.5 \mathrm{~m}$. At each grid point, one seed bag was buried $5 \mathrm{~cm}$ below the soil surface, so that each plot contained all treatment x species combinations. Seed bags were buried in the field in June 1998, early in the natural cycle of seed dispersal, and were recovered in late October 1998, at the end of the growing season. After recovery, seed bags were opened and their contents spread over potting mix in $10 \mathrm{~cm}$ square pots. In a very small number of bags, one or two Bromus or Elymus seedlings had germinated and forced their way through the bag to the soil surface; these seedlings were added to the total number of seedlings germinated in the greenhouse. Pots were kept moist in the greenhouse for 3 months. After 1.5 months, seedlings were counted and soil was disturbed to allow the more deeply buried seeds a better chance to germinate. A final count of seedlings was done at the end of the 3 month germination period. We refer to seeds detected by germination as "recovered".

\section{ANALYSIS}

The primary analysis variable was the proportion of seeds of each species that germinated; these values were arcsin transformed to improve normality (Kirk 1982). The basic analyses used were 3-factor randomized block factorial ANOVAs (Type III sums of squares), with blocking by plot, and with origin, fungicide treatment, and genus of each congeneric pair as factors. The presence of a significant fungicide $\mathrm{x}$ origin $\mathrm{x}$ genus interaction would indicate that the impacts of pathogens on aliens (relative to natives) is taxon-dependent, and thus that results may be statistically confounded or obscured by phylogeny; conversely, the lack of such an interaction indicates that fungal effects (if any) are consistent across taxonomic groups.

For all analyses, a non-interactive model was used, as recommended by Newman, Bergelson \& Grafen (1997): treatment was treated as a fixed effect, plot was treated as a random blocking effect, and the residual was used as the error term. Of the 600 and 540 experimental replicates 
respectively comprising the wetland and upland experiments, 17 and 3 were missing because seed bags were not relocated. To restore the design, these cells were interpolated using treatment $\mathrm{x}$ species means, and adjusting degrees of freedom accordingly (Underwood 1997).Wetland and upland habitats differed with respect to many factors, including their responses to experimental treatments, and were analyzed separately. Means are reported \pm 1 standard error.

\section{Results}

\section{SEED RECOVERY}

For each species, rates of seed recovery (= germination) were strongly correlated between upland and wetland habitats $\left(r_{\text {controls }}=0.87 ; r_{\text {fungicide }}=0.84 ; n=30, P<0.0001\right.$ for both tests: Fig. 1$)$. Recovery tended to be lower in wetlands than uplands, but this difference was less pronounced for fungicide-treated seeds (Fig. 2). Recovery differed significantly between plots in upland habitats, though not in wetlands (Tables 2 \& 3): overall values for the 10 wetland plots ranged from $16.9 \%$ to 22.6\%, while rates for the 9 upland plots ranged from $24.8 \%$ to $31.3 \%$. Recovery also varied significantly among taxa in both habitats (Tables $2 \& 3$ ). In the upland trial, recovery rates for 6 species were less than 5\% while recovery rates exceeded 50\% for 7 species (Fig. 3). Highest recovery rates were obtained for Lepidium densiflorum (84.7\%) and Senecio vulgaris (81.7\%) (Fig. 3). In the wetland trial 10 species had recovery rates below 5\% (the same 6 species as in the upland trial plus 4 additional species) (Fig. 3). Only Chenopodium album (59.8\%), Lepidium densiflorum (58.9\%) and Senecio vulgaris (52.8\%) had recovery rates above 50\% (Fig. 3).

\section{EFFECTS OF FUNGICIDE ADDITION}

Higher rates of fungal attack reduced the recovery of seeds from wetlands, relative to uplands. Fungicide addition significantly improved seed recovery in the wetland trial from $18.0 \% \pm 1.3 \%$ to $22.4 \% \pm 1.5 \%$ (Fig. 2 ; Table 2 ). In contrast, fungicide had no effect on recovery in the 
upland trial ( $28.3 \% \pm 1.7 \%$ control vs. $28.6 \% \pm 1.7 \%$ fungicide addition) (Fig. 2; Table 2). The tendency for the same species to have lower rates of recovery in wetlands than in uplands was nearly eliminated in the fungicide addition treatment (Fig. 1): this tendency was highly significant in the controls $(Z=-4.498 ; P<0.0001)$ but was reduced in the fungicide addition treatment $(Z=-2.300 ; P=$ 0.02) (Wilcoxon signed rank tests).

\section{VARIATION IN RECOVERY BY ORIGIN}

Aliens tended to be recovered at a greater rate than natives in both the upland and wetland trials (Fig. 2); this difference was significant in the uplands, but not wetlands (Tables $2 \& 3$ ). There were highly significant origin $\mathrm{x}$ genus interactions in both habitats, indicating that relative recovery of exotics vs. natives differed from one genus to another (Fig. 3; Tables $2 \& 3$ ).

Origin $\mathrm{x}$ fungicide treatment interactions were non-significant in both habitats, indicating that native and alien species behaved similarly in their responses to fungicide addition (Tables $2 \&$ 3). In uplands, where overall response to fungicide addition was non-significant, native recovery was 2.4\% lower in fungicide addition treatments, while alien recovery was only $4.2 \%$ greater (Fig. 2). In the wetland trial, where fungicide addition produced a significant overall increase in recovery, both natives and exotics were affected similarly: native recovery increased by $22.4 \%$ and alien recovery increased by 26.3\% (Fig. 2). Restricting analyses to congeneric pairs in which both species occur at Joker's Hill did not alter our principal conclusions: fungicide effects remain highly significant in wetland habitats $\left(F_{1,351}=19.25 ; P<0.001\right)$ but not in upland habitats $\left(F_{1,312}=0.10 ; P>0.05\right)$, whereas responses to fungicide still did not differ between natives and exotics (wetland: $F_{1,351}=$ 0.57, $P>0.05$; upland: $F_{1,312}=0.06, P>0.05$ ).

The relative responses of exotics and natives to fungicide did not depend on relationship. Rates of recovery were not correlated between members of each congeneric pair, in any treatment or 
habitat $(r<0.25 ; n=15 ; P>0.4$ : Fig. 4); this indicates that congenerics did not in general behave similarly. There were no significant three-way interactions, indicating that relationship did not influence origin $\mathrm{x}$ fungicide interactions in either habitat (Tables $2 \& 3$ ).

\section{Discussion}

\section{EFFECTS OF FUNGAL MORTALITY ON SEED PERSISTENCE IN THE SOIL}

This experiment demonstrates that soil fungi can reduce the recovery of viable seeds of a taxonomically broad range of native and exotic species, at least in wetland soils. The particular fungi involved in seed decomposition in natural soils are poorly understood, although those causing seed rots of agricultural plants are comparatively well researched (Agarwal \& Sinclair 1997; Neergaard 1977). Potentially important species include members of Oomycota (Pythium spp., Phythopthora spp.), Basidiomycota (Rhizoctonia spp.) and imperfect members of the Ascomycota (e.g. Alternaria spp, Botrytis spp.). As a result of physiological differences, few fungicides are equally effective against all groups (Paul, Ayres \& Wyness 1989), but Captan is widely used in agriculture to control species of oomycetes, ascomycetes, and basidiomycetes in the soil and on fruit, leaf, and seed surfaces (Sharvelle 1961; Torgeson 1969; Neergaard 1977). Consequently, our results are likely to reflect the collective impacts of a wide range of fungal taxa.

In our study, the effects of fungicide addition generally were small in magnitude; however, our estimates of fungal impacts probably are conservative for several reasons. First, some pathogens may have been resistant, especially since our frequency of application was low compared to many agricultural systems. Secondly, lack of specificity may have resulted in unintended negative effects of Captan on non-target mutualists (Sharvelle 1961; Torgeson 1969; Neergaard 1977); we believe this is unlikely to be a serious problem both because we focussed this study on dormant seeds, which are unlikely to be dependent on mycorrhizae, and because we observed significant positive effects of 
fungicide addition, rather than the negative effects expected if we were harming mutualists more strongly than pathogens. Finally, it is probable that some of the seeds that failed to germinate still were dormant, rather than dead; thus, our data provide only a minimum estimate of viability. Since dormant seeds should occur in all experimental treatments, their occurrence should not affect our detection of significant treatment effects or interactions. However, dormancy may have contributed to lower rates of recovery for some species, exaggerating interspecific differences and obscuring treatment effects by preventing the detection of viable seeds.

There are a number of other lines of evidence suggesting the importance of fungi to soil seed banks in natural habitats. Soil fungi (including Oomycota) are ubiquitous and abundant (Dix \& Webster 1995). Many fungal plant pathogens, including some which can have significant population level effects, are soil borne (Dinoor \& Eshed 1984; Burdon 1987). Finally, the importance of fungicidal seed coatings in agriculture (Taylor \& Harman 1990) and the presence of fungalinhibiting compounds in seed coats (Baskin \& Baskin 1998) suggest that soil fungi are an important source of seed mortality. Despite these lines of evidence, few other studies demonstrate the occurrence of fungal mortality in seeds and seedlings in natural plant communities, though there are examples from several very different ecosystems. Crist \& Friese (1993) found that proportions of decomposed seeds among 5 shrub-steppe species ranged from $<5 \%$ to $93.5 \%$ over 10 months. They implicated fungi as a causal agent by isolating 7 fungal species from the retrieved seeds. Lonsdale (1993) demonstrated that seed survival of the exotic Mimosa pigra in northern Australia increased by $10 \%-16 \%$ over 7 months following the addition of fungicide to the soil. Augsburger (1983) and Augspurger \& Kelly (1984) demonstrated that damping-off disease killed 0-95\% of seedlings of a wide range of tropical tree species, and that mortality increased with seedling density, shade and proximity to the parent tree. Packer \& Clay (2000) found Pythium caused significant mortality in 
seedlings of the temperate tree Prunus serotina. Finally, Leishman et al. (2000) found fungicide significantly increased recovery of intact seeds of some, but not all, experimental species of in a British grassland.

\section{VARIATION IN FUNGAL MORTALITY BETWEEN WETLANDS AND UPLANDS}

Seed recovery in controls consistently was lower in wetland sites than in uplands. The fact that fungicide addition reduced this difference by improving wetland recovery indicates that it was largely attributable to a higher level of fungal mortality in wetlands. There is evidence that fungal pathogens generally are more prevalent in moist soils than in dry soils. The best example comes from Augspurger (1983) and Augspurger \& Kelly (1984), whose studies of spatial variation in the rates of damping-off mortality in tropical tree seedlings showed that mortality was greater in low light areas with higher soil moisture and humidity. Rotem (1978) suggests that this is a general trend which may apply to non-fungal plant pathogens as well. Apparent counterexamples do exist: Leishman et al. (2000) found that supplementing summer rainfall did not lead to higher levels of fungal mortality for seeds of four experimental species.

Alternatively, though few studies have examined the effects of soil moisture on seed bank survival in natural plant communities, limited evidence suggests that seeds survive best in the moisture range in which they typically occur (Leck 1996). If so, fungally-induced seed mortality could limit the penetration of wetlands by upland species, and could help to define wetland boundaries. Our results are consistent with this hypothesis: we deliberately chose species largely restricted to uplands and found that recovery was greatest in upland habitats. In a mesocosm experiment using turves collected from the field, Bekker, Oomes \& Bakker (1998) also found that seeds of species typical of dry grasslands tended to survive best in a low water treatment, while wet grassland species survived best in a high water treatment. 


\section{VARIATION IN FUNGAL MORTALITY BETWEEN NATIVES AND EXOTICS}

We found that responses to fungicide additions did not differ between native and exotic species in either wetland or upland habitats. The most likely explanation is that the most important pathogens were generalist fungi which did not distinguish between seeds of natives and aliens; many soil-borne plant pathogens and decay organisms are known to be generalists (Dix \& Webster 1995). It is also possible that pathogens specific to native species have become adapted to aliens since their introduction, or that specialist pathogens may have been introduced along with their plant hosts. Some fungal and other pathogens can be transported with seeds (Neergaard 1977; Kirkpatrick \& Bazzaz 1979; Agarwal \& Sinclair 1997), which are probably the form in which most exotic plants are introduced. In any case, it is clear that alien status per se did not result in a lower pest load for exotics than for related natives.

These results strongly argue against the predator escape hypothesis: if exotics are escaping species-specific seed pathogens when colonizing new regions, this escape must be temporary at best. The lack of differential response also suggests that the filter hypothesis does not apply: there is little reason to believe that the exotics that have successfully established in these habitats have unusually low intrinsic pest loads, at least compared to native congeners. It is still possible that predator filters may operate at higher taxonomic levels: the majority of exotics may come from genera that are relatively pest-resistant. However, in two studies in which we did not employ congeneric pairs, but instead used larger and more taxonomically diverse sets of locally-occurring species, we found no evidence that this was the case for either seed predators (Blaney \& Kotanen 2001) or soil fungi (Blaney 1999, Blaney \& Kotanen unpublished data). 


\section{SEED BANKING AND INVASIONS}

Our study was designed around the idea that invasiveness may be increased amongst species with a persistent seed bank. However, population growth or spread of invaders may often be controlled more strongly by interactions involving other life history stages. For example, a recent survey suggests that many plant populations, especially in mesic grasslands, are limited by microsite or growing conditions rather than by the availability of viable seed (Turnbull, Crawley \& Rees 2000). Invasion is also a multi-stage event (e.g. Williamson 1996; Mack et al. 2000); as a result, processes operating during initial establishment may differ from those during spread or following the development of naturalized populations. For example, a persistent seed bank may well be an advantage during the earliest stages of an invasion, when it may enhance the persistence of small founder populations (Venable \& Brown 1988), but by removing seeds from the actively growing population it also may reduce subsequent population growth and spread (Rees \& Long 1992; Rees 1997). Tradeoffs between dormancy and dispersal (Rees 1993, 1997) also may reduce the rate of spread of species with a persistent seed bank. Finally, in naturalized populations, delayed germination again may improve population persistence, depending on details of temporal and spatial variability, and the nature of interspecific interactions (Venable \& Brown 1988; Rees \& Long 1992; Rees 1997). Conflicts of this kind suggest that the seed ecology of different invaders may represent different strategies: some may rely more on persistence, some on spread (Thompson, Hodgson \& Rich 1995; Crawley et al. 1996; Hodkinson \& Thompson 1997).

We did find one intriguing difference between the seed bank dynamics of natives and exotics: seeds of exotics were more likely to be recovered than seeds of natives in upland habitats. Fungi apparently were not responsible for this difference, since exotics and natives in uplands did not differ in their lack of response to fungicide. The explanation instead may lie with lower 
susceptibility of exotics to non-fungal sources of mortality, such as poor seed longevity, inappropriate germination, or bacterial pathogens (Baskin \& Baskin 1998); the upland species that we used apparently lose this advantage in wetter soils. These results suggest that at least in dry soils, exotics tend to form more persistent seed banks than natives, as also reported by Crawley et al. (1996). This agrees with the our original hypothesis that persistent seed banks may facilitate invasions, but not because exotics have greater resistance than natives to fungal diseases. This result also supports the view that the value to invaders of characteristics such as seed dormancy is likely to be habitat-dependent (Thompson et al. 1995; Hodkinson \& Thompson 1997): strategies that work under some conditions may fail under others, obscuring efforts to identify characters that increase invasiveness.

\section{MANAGEMENT IMPLICATIONS}

Our study demonstrates that while soil pathogens reduce the survival of seeds of many native and exotic species, and while exotics may benefit from persistent seed banks, exotics are no more resistant to fungal seed pathogens than are related natives. It is important to realize that this result does not necessarily apply to other life-history stages, nor does it preclude the possibility that the most seriously invasive species are exceptions to this rule: they may be problems precisely because they enjoy atypically low pathogen levels. Certain spectacularly successful biological control efforts, as with Opuntia spp. in Australia (Mann 1970) and South Africa (Zimmermann, Moran \& Hoffmann 1986), and Hypericum perforatum in California (Huffaker \& Kennett 1959), suggest this to be true for some plant invaders: these were species whose success was dependent upon escape from insect natural enemies. However, the fact that most biological control efforts fail (Crawley 1986) also suggests that these examples may be exceptional. Comparing invasions in which low predator or 
pathogen loads are important, and the probable majority in which they are not, may improve efforts at biological control as well as our general understanding of biological invasions.

Our results also demonstrate the need for caution. The apparently generalist nature of most soil seed pathogens and the lack of consistent differences between natives and exotics suggest that it may be very difficult to develop control agents or management strategies that target seeds of exotics without negatively affecting at least some natives. For example, attempts to enhance fungal populations, or to deploy fungal biocontrol agents, may equally harm target exotics and susceptible non-target natives. Conversely, fungicide applications may improve recruitment of native species, but are likely to increase populations of some exotics as well. Such considerations do not apply only to fungal pathogens. Efforts to reduce the reproduction of exotic plants using insects have had unintended effects on non-target relatives (Pemberton 2000); for example, the flowerhead weevil Rhinocyllus conicus was introduced to North America to control seed production of exotic thistles in the genus Carduus, but has had serious non-target impacts on scarce native thistles as well (Louda et al. 1997). As with other forms of biological control (Simberloff \& Stiling 1996a,b), efforts to control exotics by manipulating their seed ecology must be undertaken with great caution. 


\section{Acknowledgements}

This research was supported by an NSERC Research Grant to PMK and an NSERC PGS to CSB. Additional support was provided by The University of Toronto, the Connaught Fund, and Human Resources Development Canada. Many students and volunteers contributed invaluable assistance, including Marc Johnson, Uyen Dias, Bill Kilburn, Vijanti Ramlogan, Joel Sotomayor, Sheenagh Bell, and numerous seed collectors. Spencer Barrett, Bob Jefferies, Linda Kohn, and Gary Sprules all contributed invaluable advice and guidance, and comments by Leslie Ambedian and three anonymous reviewers improved the manuscript. Special thanks to Murray Koffler for his generous and far-sighted donation to the University of Toronto of the property that has become the Joker's Hill research station. 


\section{Literature cited}

Agarwal, V.K. \& Sinclair, J.B. (1997) Principles of Seed Pathology, 2nd edn. CRC Press, Boca Raton.

Augspurger, C.K. (1983) Seed dispersal of the tropical tree Platypodium elegans, and the escape of its seedlings from fungal pathogens. Journal of Ecology, 71, 759-771.

Augspurger, C.K. \& Kelly, C.K. (1984) Pathogen mortality of tropical tree seedlings: experimental studies of the effects of dispersal distance, seedling density, and light conditions. Oecologia, 61, 211-217.

Baker, H.G. (1969) Characteristics and modes of origin of weeds. The genetics of colonizing species (eds H.G. Baker \& G.L. Stebbins), pp. 147-168. Academic Press, New York.

Baker, H.G. (1974) The evolution of weeds. Annual Review of Ecology and Systematics, 5, 1-24.

Barrett, S.C.H. \& Richardson, B.J. (1986) Genetic attributes of invading species. Ecology of biological invasions: an Australian perspective (eds R.H. Groves \& J.J. Burdon), pp. 21-33. Cambridge University Press, Cambridge.

Barrett, S.C.H. \& Husband, B.C. (1990) The genetics of plant migration and colonization. Plant population genetics, breeding and colonization (eds A.D.H. Brown, M.T. Clegg, A.L. Kahler, \& B.S. Weir), pp. 254-277. Sinauer, Sunderland, Massachusetts.

Baskin, C.C. \& Baskin, J.M. (1998) Seeds: Ecology, Biogeography, and Evolution of Dormancy and Germination. Academic Press, San Diego.

Bekker, R.M., Oomes, M.J.M. \& Bakker, J.P. (1998) The impact of groundwater level on soil seed bank survival. Seed Science Research, 8, 399-404.

Blaney, C.S. (1999) Seed bank dynamics of native and exotic plants in open uplands of southern Ontario. M.Sc. thesis, University of Toronto. 
Blaney, C.S. \& Kotanen, P.M. (2001) Post-dispersal losses to seed predators: an experimental comparison of native and exotic old field plants. Canadian Journal of Botany, 79, 284-292.

Burdon, J.J. (1987) Diseases and plant population biology. Cambridge University Press, Cambridge. Crawley, M.J. (1986) The population biology of invaders. Philosophical Transactions of the Royal Society of London B, 314, 711-731.

Crawley, M.J. (1989) Chance and timing in biological invasions. Biological Invasions: A Global Perspective (eds J.A. Drake, H.A. Mooney, F. DiCastri, R.H. Groves, F.J. Kruger, M. Rejmánek \& M. Williamson), pp. 407-423. John Wiley and Sons, Chichester.

Crawley, M.J., Harvey P.H. \& Purvis A. (1996) Comparative ecology of the native and alien floras of the British Isles. Philosophical Transactions of the Royal Society of London, 351, 1251-1259. Crist, T.O. \& Friese, C.F. (1993) The impact of fungi on soil seeds: Implications for plants and granivores in a semiarid shrub-steppe. Ecology, 74, 2231-2239.

Dahlsten, D.L. (1986) Control of invaders. Ecology of Biological Invasions of North America and Hawaii (eds H.A. Mooney \& J.A. Drake), pp. 275-302. Springer-Verlag, New York.

Dean, S.J., Holmes, P.M. \& Weiss, P.W. (1986) Seed biology of invasive alien plants in South Africa and South West Africa / Namibia. The ecology and management of biological invasions in southern Africa (eds S.J. Dean, P.M. Holmes \& P.W. Weiss), pp. 157-170. Oxford University Press, Cape Town.

Dinoor, A. \& Eshed, N. (1984) The role and importance of pathogens in natural plant communities. Annual Review of Phytopathology, 22, 443-466.

Dix, N., \& Webster, J. (1995) Fungal ecology. Chapman and Hall, London.

Drake, J.A., Mooney, H.A., Di Castri, F., Groves, R.H., Kruger, F.J., Rejmánek, M. \& Williamson, M. (eds.) (1989) Biological Invasions: A Global Perspective. John Wiley and Sons, Chichester. 
Elton, C.S. (1958) The Ecology of Invasions by Animals and Plants. Methuen, London.

Felsenstein, J. (1985) Phylogenies and the comparative method. The American Naturalist, 125, 1-15.

Fenner, M (ed.). (1992) Seeds: The ecology of regeneration in plant communities. CAB International, Wallingford.

Gleason, H.A. \& Cronquist, A. (1991) Manual of the Vascular Plants of the Northeast United States and Adjacent Canada, 2nd edn. New York Botanical Garden, New York.

Harman, G.E. (1983) Mechanisms of seed infection and pathogenesis. Phytopathology, 73, 326-329.

Harper, J. (1977) Population Biology of Plants. Academic Press, London.

Harvey, P.H. \& Pagel, M.D. (1991) The Comparative Method in Evolutionary Biology. Oxford University Press, Oxford.

Hodkinson, D.J. \& Thompson, K. (1997) Plant dispersal: the role of man. Journal of Applied Ecology, 34, 1484-1496.

Holm, L.G., Plunkett, D.L., Pancho, J.V. \& Herberger, H.P. (1977) The World’s Worst Weeds: Distribution and Biology. University Press of Hawaii, Honolulu.

Holloway, J.K. (1964) Projects in the biological control of weeds. Biological Control of Insect Pests and Weeds (ed. P. DeBach), pp. 650-652. Reinhold Publishing Corporation, New York.

Huffaker, C.B. \& Kennett, C.E. (1959) A ten-year study of vegetational changes associated with biological control of Klamath Weed. Journal of Range Management, 12, 69-82.

Karieva, P. (1996) Developing a predictive ecology for non-indigenous species and ecological invasions. Ecology, 77, 1651-1652.

Kirk, R.E. (1982) Experimental design: procedures for the behavioural sciences, 2nd edn. Brooks and Cole, Monterey. 
Kirkpatrick, B.L. \& Bazzaz, F.A. (1979) Influence of certain fungi on seed germination and seedling survival of four colonizing annuals. Journal of Applied Ecology, 16, 515-527.

Kremer, R.J. (1993) Management of weed seed banks with microorganisms. Ecological

Applications, 3, 42-52.

Kolar, C.S. \& Lodge, D.M. (2001) Progress in invasion biology: predicting invaders. Trends in Ecology and Evolution, 16, 199-204.

Leck, M.A. (1996) Germination of macrophytes from a Delaware River tidal freshwater wetland. Bulletin of the Torrey Botanical Club, 123, 48-67.

Leck, M.A, Parker, V.T. \& Simpson, R.L. (eds) (1989) Ecology of Soil Seed Banks. Academic Press, San Diego, California.

Leishman, M.R., Masters, G.J., Clarke, I.P. \& Brown, V.K. (2000) Seed bank dynamics: the role of fungal pathogens and climate change. Functional Ecology, 14, 293-299.

Lonsdale, W.M. (1993) Losses from the seed bank of Mimosa pigra: Soil micro-organisms vs. temperature fluctuations. Journal of Applied Ecology, 30, 654-660.

Louda, S.M., Kendall, D., Connor, J. \& Simberloff, D. (1997) Ecological effects of an insect introduced for the biological control of weeds. Science, 277, 1088-1090.

Mack, R.N. (1996) Predicting the identity and fate of plant invaders: Emergent and emerging approaches. Biological Conservation, 78, 107-121.

Mack, R.N., Simberloff, D., Lonsdale, W.M., Evans, H., Clout, M. \& Bazzaz, F.A. (2000) Biotic invasions: causes, epidemiology, global consequences, and control. Ecological Applications, 10, 689-710.

Manchester, S.J. \& Bullock, J.M. (2000) The impacts of non-native species on UK biodiversity and the effectiveness of control. Journal of Applied Ecology, 37, 845-864. 
Mann, J. (1970) Cacti naturalized in Australia and their control. Government Printer, Brisbane. Miles, D.B. \& Dunham, A.E. (1993) Historical perspectives in ecology and evolutionary biology. Annual Review of Ecology and Systematics, 24, 587-619.

Mills, K.E. \& Bever, J.D. (1998) Maintenance of diversity within plant communities: soil pathogens as agents of negative feedback. Ecology, 79, 1595-1601.

Morton, J.K. \& Venn, J.M. (1990) A Checklist of the Flora of Ontario: Vascular Plants. University of Waterloo Biology Series, Waterloo.

Neergaard, P. (1977) Seed Pathology, Vol. I. Halsted Press, New York.

Newman, J.A., Bergelson, J. \& Grafen, A. (1997) Blocking factors and hypothesis tests in ecology: is your statistics text wrong? Ecology, 78, 1312-1320.

Packer, A. \& Clay, K. (2000) Soil pathogens and spatial patterns of seedling mortality in a temperate tree. Nature, 404, 278-281.

Paul, N.D., Ayres, P.G. \& Wyness, L.E. (1989) On the use of fungicides for experimentation in natural vegetation. Functional Ecology, 3, 759-769.

Pemberton, R.W. (2000) Predictable risk to native plants in biological weed control. Oecologia, 125, 489-494.

Rees, M. (1993) Trade-offs among dispersal strategies in British plants. Nature, 366, 150-152.

Rees, M. \& Long, M.J. (1992) Germination biology and the ecology of annual plants. The American Naturalist, 139, 484-508.

Rees, M. (1997) Evolutionary ecology of seed dormancy and seed size. Plant Life Histories: Ecology, Phylogeny and Evolution (eds J. Silvertown, M. Franco \& J.L. Harper), pp. 121-142. Cambridge University Press, Cambridge. 
Riley, J.L. (1989) Distribution and Status of the Vascular Plants of Central Region. Ontario Ministry of Natural Resources Central Region, Richmond Hill.

Rotem, J. (1978). Climatic and weather influences on epidemics. Plant Disease - An Advanced Treatise, Vol. II (eds J.G. Horsfall \& E.B. Cowling), pp. 317-337. Academic Press, New York. Scott, J.K. (1996) Population ecology of Chrysanthemoides monilifera in South Africa: implications for its control in Australia. Journal of Applied Ecology, 33, 1496-1508.

Sharvelle, E.G. (1961) The Nature and Uses of Modern Fungicides. Burgess Publishing, Minneapolis.

Simberloff, D. \& Stiling, P. (1996a) How risky is biological control? Ecology, 77, 1965-1974.

Simberloff, D. \& Stiling, P. (1996b) Risks of species introduced for biological control. Biological Conservation, 78, 185-192.

Stöcklin, J. \& Fischer, M. (1999) Plants with longer-lived seeds have lower extinction rates in grassland remnants 1950-1985. Oecologia, 120, 539-543.

Taylor, A.G. \& Harman, G.E. (1990) Concepts and technologies of selected seed treatments. Annual Review of Phytopathology, 28, 321-340.

Thompson, K., Hodgson, J.G. \& Rich, T.C.G. (1995) Native and alien invasive plants: more of the same? Ecography, 18, 390-402.

Torgeson, D.C. (ed.) (1969) Fungicides: An Advanced Treatise, Volume II: Chemistry and Physiology. Academic Press, New York.

Turnbull, L.A., Crawley, M.J. \& Rees, M. (2000) Are plant populations seed-limited? A review of sowing experiments. Oikos, 88, 225-238.

Underwood, A.J. (1997) Experiments in Ecology. Cambridge University Press, Cambridge. 
U.S. Congress, Office of Technology Assessment 1993. Harmful non-indigenous species in the United States (OTA-F-565). U.S. Government Printing Office, Washington.

Venable, D.L. \& Brown, J.S. (1988) The selective interactions of dispersal, dormancy, and seed size as adaptations for reducing risk in variable environments. The American Naturalist, 131, 360-384.

Vitousek, P.M., D’Antonio, C.M., Loope, L.L. \& Westbrooks, R. (1996) Biological Invasions as Global Environmental Change. American Scientist, 84, 468-478.

Vyas, S.C. (1988) Nontarget effects of agricultural fungicides. CRC Press, Boca Raton.

Williamson, M. (1996) Biological Invasions. Chapman and Hall, London.

Williamson, M. \&. Fitter, A. (1996a) The varying success of invaders. Ecology, 77, 1661-1666.

Williamson, M. \& Fitter, A. (1996b) The characteristics of successful invaders. Biological Conservation, 78, 163-170.

Zimmermann, H.G., Moran, V.C. \& Hoffmann, J.H. (1986) Insect herbivores as determinants of the present distribution and abundance of invasive cacti in South Africa. Ecology and Management of Biological Invasions in Southern Africa (eds I.A.W. Macdonald, F.J. Kruger, A.A. Ferrar), pp. 269-274. Oxford University Press, Cape Town. 
Table 1 Experimental species. Presence on Joker's Hill research station property (JH) is indicated by an “x”. Native or alien origin follows Morton \& Venn (1990) and nomenclature follows Gleason \& Cronquist (1991).

\begin{tabular}{|c|c|c|c|}
\hline Congeneric pair & Species & Origin & $\mathrm{JH}$ \\
\hline \multirow[t]{2}{*}{ ASTERACEAE 1} & Lactuca canadensis & native & $\mathrm{x}$ \\
\hline & Lactuca serriola & alien & $\mathrm{x}$ \\
\hline \multirow[t]{2}{*}{ ASTERACEAE 2} & Senecio pauperculus & native & \\
\hline & Senecio vulgaris & alien & $\mathrm{x}$ \\
\hline \multirow[t]{2}{*}{ BRASSICACEAE } & Lepidium densiflorum & native & $\mathrm{x}$ \\
\hline & Lepidium campestre & alien & $\mathrm{x}$ \\
\hline \multirow[t]{2}{*}{ CAMPANULACEAE } & Campanula rotundifolia & native & $\mathrm{x}$ \\
\hline & Campanula rapunculoides & alien & $\mathrm{x}$ \\
\hline \multirow[t]{2}{*}{ CARYOPHYLLACEAE } & Cerastium arvense & native & \\
\hline & Cerastium fontanum & alien & $\mathrm{x}$ \\
\hline \multirow[t]{2}{*}{ CARYOPHYLLACEAE } & Silene antirrhina & native & $\mathrm{x}$ \\
\hline & Silene vulgaris & alien & $\mathrm{x}$ \\
\hline \multirow[t]{2}{*}{ CHENOPODIACEAE } & Chenopodium simplex & native & $\mathrm{x}$ \\
\hline & Chenopodium album & alien & $\mathrm{x}$ \\
\hline \multirow[t]{2}{*}{ CYPERACEAE } & Carex muhlenbergii & native & $\mathrm{x}$ \\
\hline & Carex spicata & alien & $\mathrm{x}$ \\
\hline \multirow[t]{2}{*}{ PLANTAGINACEAE } & Plantago rugellii & native & $\mathrm{x}$ \\
\hline & Plantago major & alien & $\mathrm{x}$ \\
\hline
\end{tabular}


POACEAE 1

Bromus kalmii

native

Bromus inermis

alien

$\mathrm{X}$ 
Table 1 (continued)

\begin{tabular}{llll}
\hline POACEAE 2 & Elymus trachycaulus & native & \\
& Elymus repens & alien & $\mathrm{x}$ \\
POLYGONACEAE & Polygonum cilinode & native & \\
& Polygonum convolvulus & alien & $\mathrm{x}$ \\
ROSACEAE 1 & Geum aleppicum & native & $\mathrm{x}$ \\
& Geum urbanum & alien & $\mathrm{x}$ \\
ROSACEAE 2 & Potentilla arguta & native & $\mathrm{x}$ \\
& Potentilla recta & alien & $\mathrm{x}$ \\
RUBIACEAE & Galium boreale & native & $\mathrm{x}$ \\
& Galium verum & alien & $\mathrm{x}$ \\
\hline Total & 30 species & $(15$ native, 15 alien $)$ \\
\hline
\end{tabular}


Table 2 Results of the upland trial. Analysis of variance of the effects of fungicide addition, genus, origin (native vs. exotic), and plot on recovery of experimental seeds. Fungicide, origin, and genus were treated as fixed effects, plot was treated as a randomized block, and the residual was used as the error term.

\begin{tabular}{lccl}
\hline Factor & df & MS & $F$-Value \\
\hline plot & 8 & 0.414 & $3.767^{* * *}$ \\
fungicide & 1 & 0.004 & 0.034 \\
origin & 1 & 1.838 & $15.715^{* * *}$ \\
genus & 14 & 11.302 & $96.634^{* * *}$ \\
fungicide x origin & 1 & 0.125 & 1.069 \\
fungicide x genus & 14 & 0.243 & $2.078^{*}$ \\
origin x genus & 14 & 7.179 & $61.381^{* * *}$ \\
fungicide x origin $x$ genus & 14 & 0.093 & 0.795 \\
error & 469 & 0.117 & \\
\hline$*=P<0.01, * *=P<0.001, * * *=P<0.0001$ &
\end{tabular}


Table 3 Results of the wetland trial. Analysis of variance of the effects of fungicide addition, genus, origin (native vs. exotic), and plot on recovery of experimental seeds. Fungicide, origin, and genus were treated as fixed effects, plot was treated as a randomized block, and the residual was used as the error term.

\begin{tabular}{|c|c|c|c|}
\hline Factor & $\overline{d f}$ & MS & F-Value \\
\hline plot & 9 & 0.188 & 1.359 \\
\hline fungicide & 1 & 3.039 & $21.969 * * *$ \\
\hline origin & 1 & 0.105 & 0.759 \\
\hline genus & 14 & 8.700 & $62.892 * * *$ \\
\hline fungicide $\mathrm{x}$ origin & 1 & 0.070 & 0.506 \\
\hline fungicide $x$ genus & 14 & 0.170 & 1.229 \\
\hline origin $\mathrm{x}$ genus & 14 & 5.871 & $42.441^{* * *}$ \\
\hline fungicide $\mathrm{x}$ origin $\mathrm{x}$ genus & 14 & 0.144 & 1.041 \\
\hline error & 514 & 0.138 & \\
\hline
\end{tabular}




\section{Figure Legends}

Fig. 1 Recovery of seeds of each experimental species in uplands and wetlands, separated by treatment. Each datapoint represents the mean values for a single species; the diagonal line is the line of equality (equal recovery in both habitats). Filled circles ( $\mathrm{J}$ ) represent native species; open circles (E) represent exotics.

Fig. 2 Overall proportion of seeds recovered in uplands and wetlands (all species pooled). Origin (alien vs. native) and fungicide treatment (addition vs. control) are indicated. Error bars are +1 SEM. Fig. 3 Proportion of seeds of each experimental species recovered in uplands and wetlands. Origin (alien vs. native) and fungicide treatment (addition vs. control) are indicated. Error bars are +1 SEM. Fig. 4 Congeneric comparisons, separated by treatment and habitat. Each datapoint represents the mean values for the recovery of seeds of one native and one congeneric exotic; the diagonal line is the line of equality (equal recovery for natives and exotics). 
Fig. 1 - Blane and Kotanen - JAE ms 2000/127
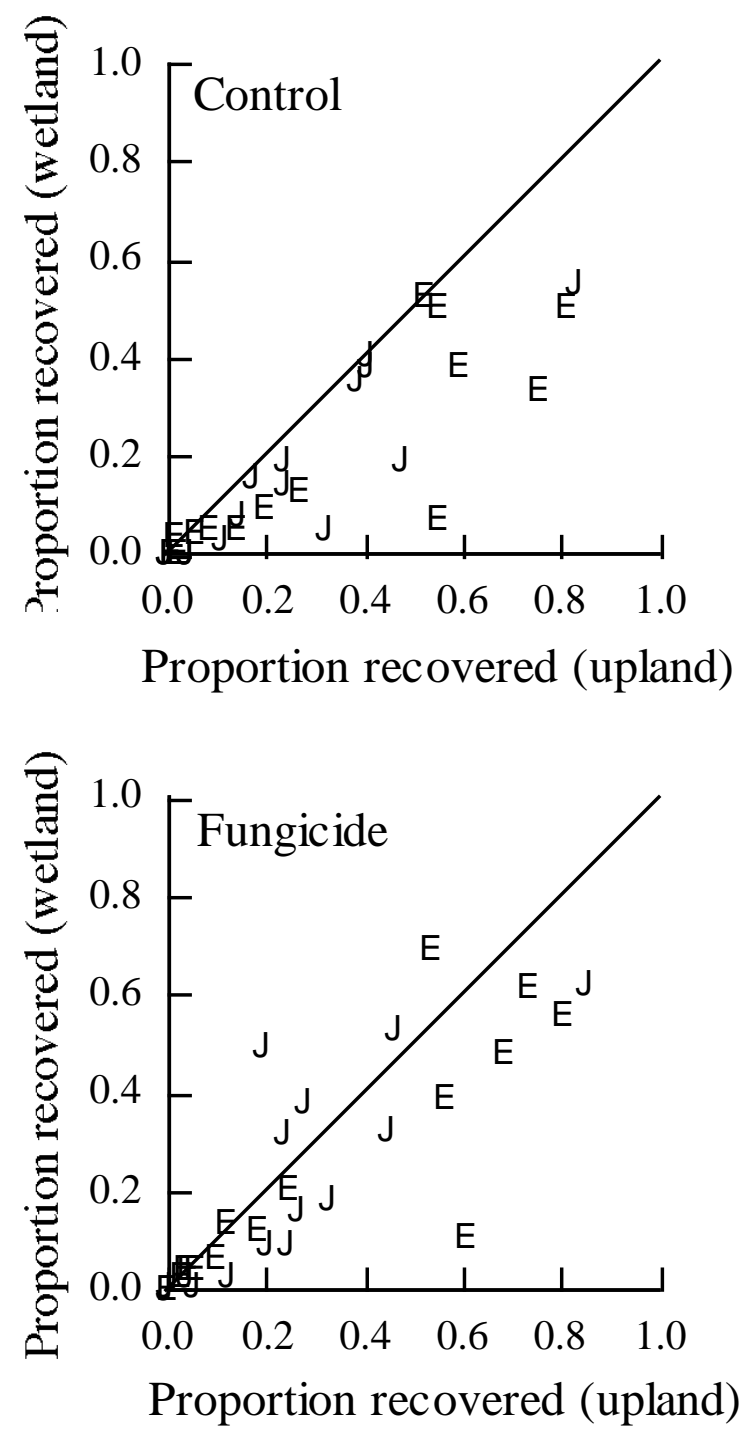
Fig. 2 - Blaney and Kotanen - JAE ms 2000/127
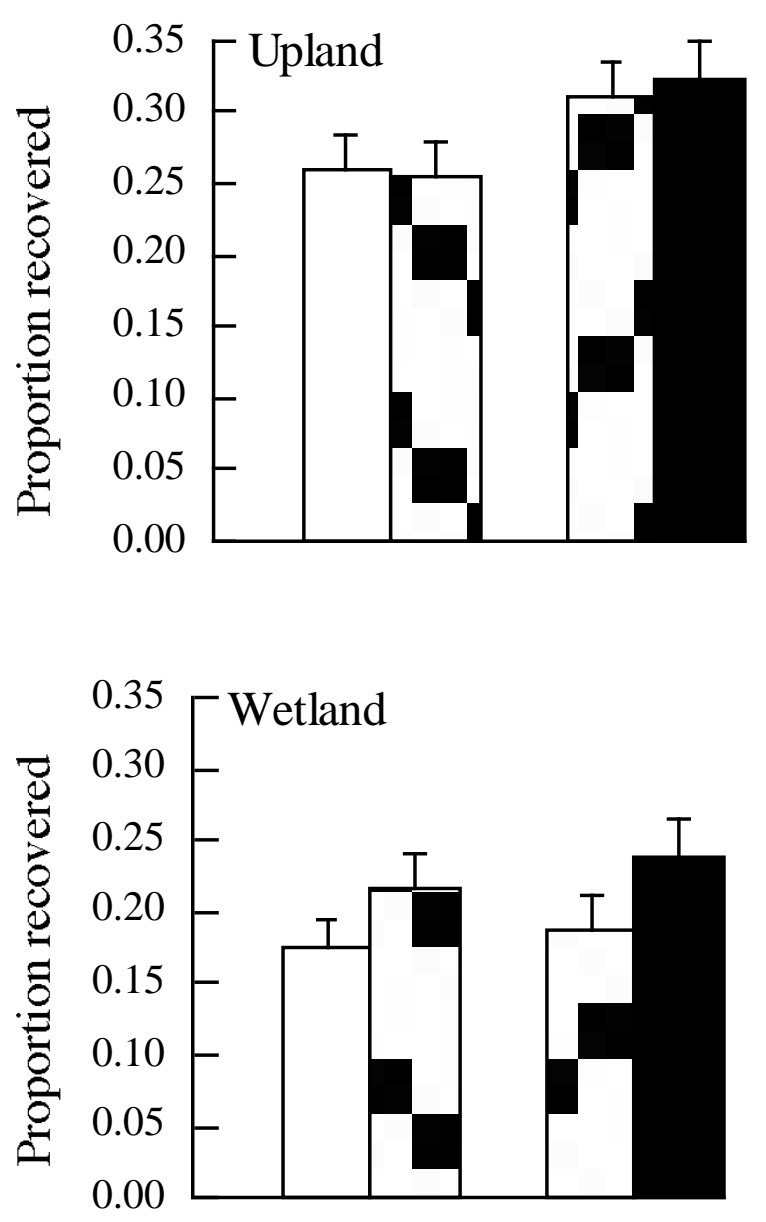
$\square$ Native - control $\square$ Alien - control
$\square$ Native - fungicide $\square$ Alien -fungicide 
Fig. 3 - Blaney and Kotanen - JAE ms 2000/127
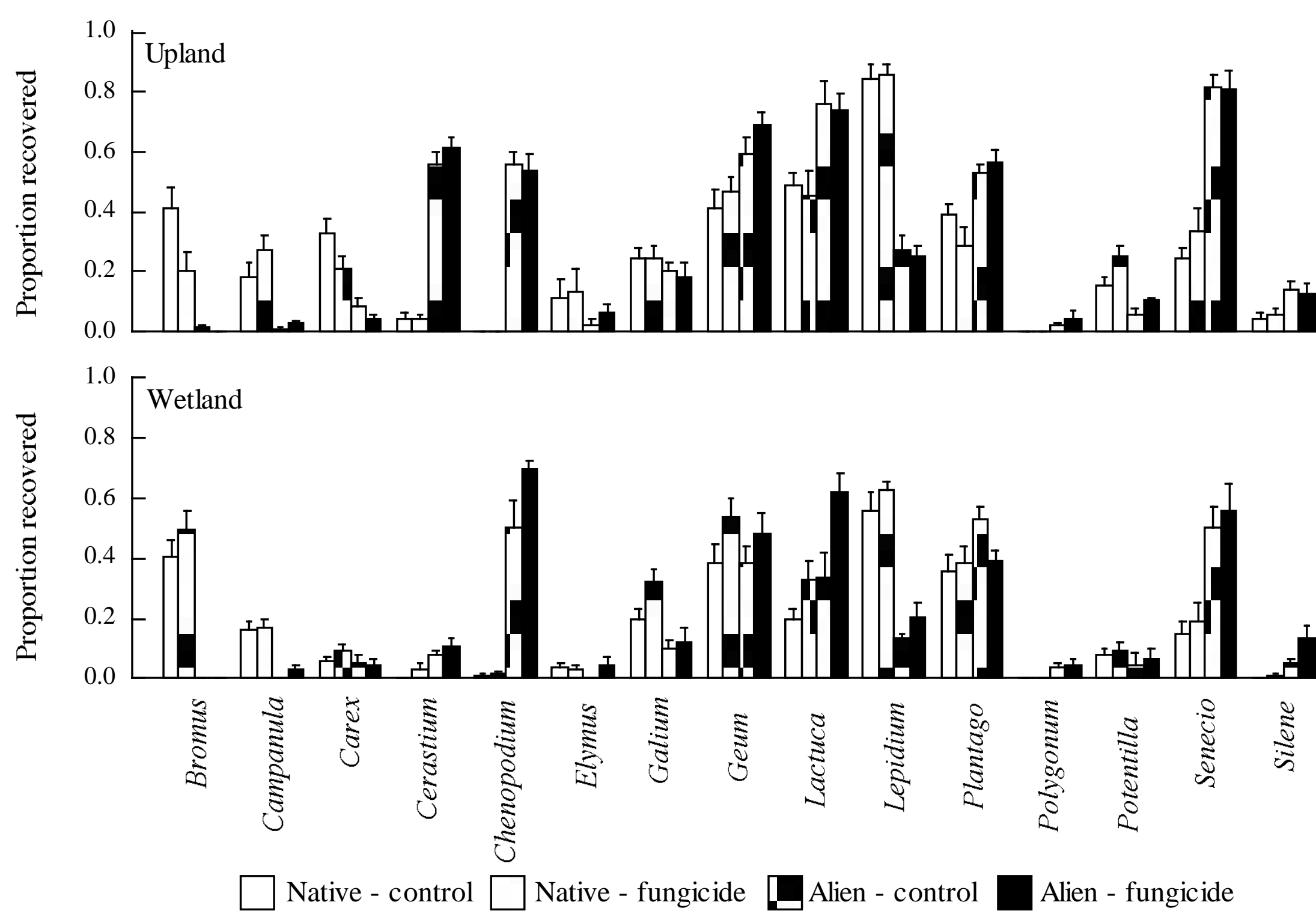
Fig. 4 3laney and Kotanen - JAE ms -00/127
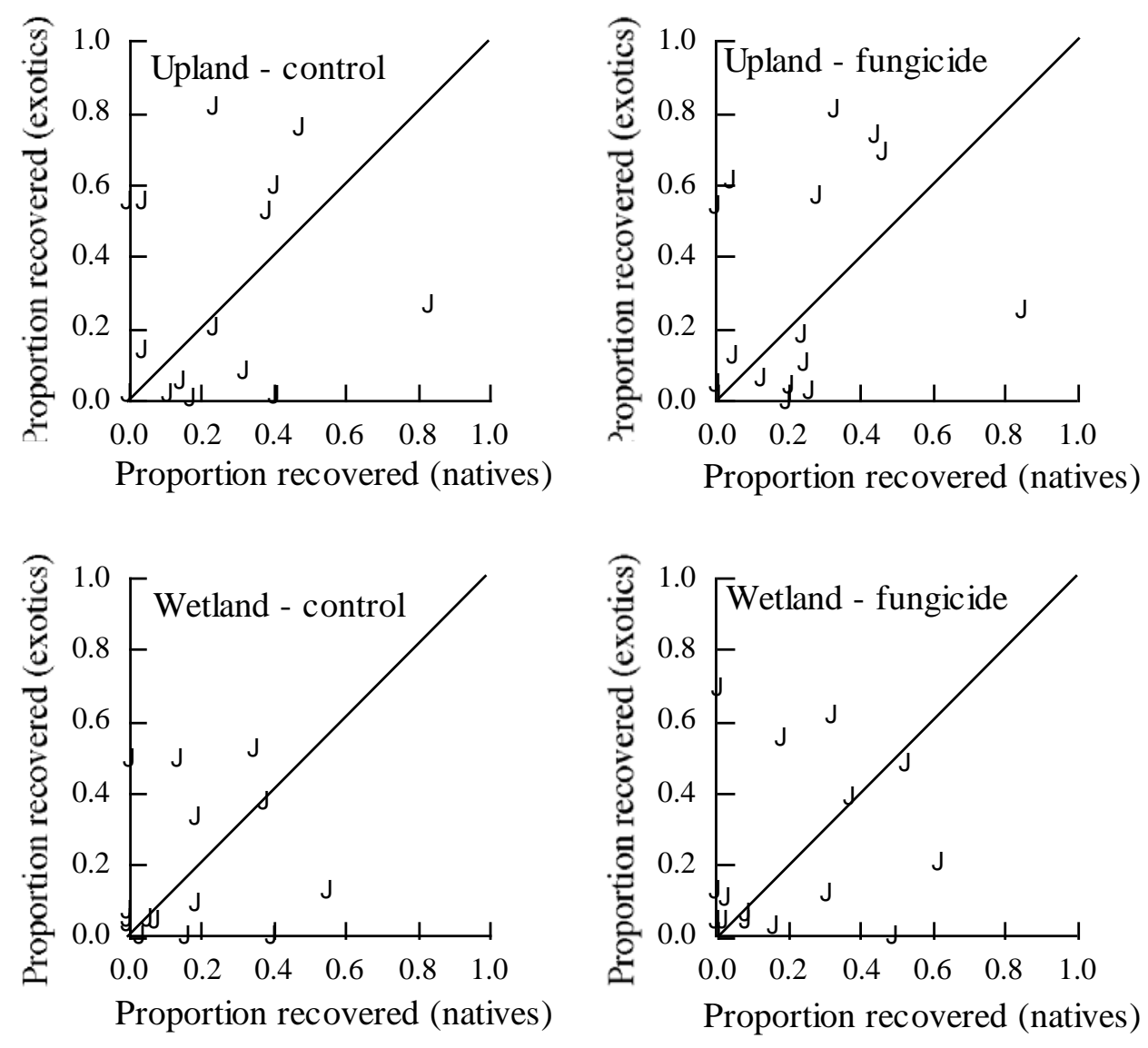